\title{
Biochar of Sawdust Origin in Passion Fruit Seedling Production
}

\author{
D. L. Barros ${ }^{1,2}$, F. A. Rezende ${ }^{3}$, A. T. Campos $^{1}$ \& C. M. B. F. Maia ${ }^{4}$ \\ ${ }^{1}$ Federal University of Lavras, Lavras, Minas Gerais, Brazil \\ ${ }^{2}$ Federal Institute of Roraima, Boa Vista, Roraima, Brazil \\ ${ }^{3}$ Embrapa Agrossilvopastoral, Sinop, Brazil \\ ${ }^{5}$ Embrapa Forestry, Colombo, Brazil \\ Correspondence: Danieli Lazarini de Barros, Instituto Federal de Roraima, BR174, Km 512, Vila Novo Paraíso, \\ Caracaraí, RR, CEP 69365-000, Brazil. Tel: 55-95-3532-4100. Email: danieli.lazarini@gmail.com
}

Received: March 7, 2017

Accepted: March 30, 2017

Online Published: April 15, 2017

doi:10.5539/jas.v9n5p200

URL: https://doi.org/10.5539/jas.v9n5p200

The research is financed by Mato Grosso Research Support Foundation (FAPEMAT), National Counsel of Technological and Scientific Development (CNPq), Flora Sinop Nursery, Coordination for the Improvement of Higher Education Personnel (Capes).

\begin{abstract}
Great part of solid waste are deposited inappropriately near cities or in rural areas, contributing to negative environmental impacts. There are numerous forms of waste processing, one of them is pyrolysis to produce biochar and subsequent use in agricultural systems. The objective of this study was to evaluate different substrates with activated biochar $(\mathrm{AB})$ and biochar $(\mathrm{B})$ in substrate and its effect on the growth of passion fruit seedlings. The test was conducted in a nursery, located in Sinop/MT, May to July 2013, designed in four blocks with ten treatments: commercial substrate (CS), composed by pine bark and vermiculite 4:1; nursery substrate (NS) composed by carbonized rice husk and coconut fiber 1:1; and the eigth treatments represented were $\mathrm{B}$ and $\mathrm{AB}$ additions of $25 ; 50 ; 75$; and $100 \%$ in $\mathrm{CS}$, (B25, B50, B75, B100, AB25, AB50, AB75 and AB100, respectively). After 60 days sowing the stem diameter, plant height, leaf number was evaluated and at the end of the experiment the fresh and dry weight of shoots and roots, and Dickson Quality Index (DQI) were assessed. $\mathrm{AB}$ at concentrations of 25,50 and $75 \%$ combined with commercial substrate showed increases in parameters fresh and dry biomass weight, height, stem diameter and number of leaves. The dose of $25 \% \mathrm{AB}$ is presented as the best dose to be adopted in commercial crops. The sawdust processed into $A B$ is an alternative in the production of passion fruit system and the reintegration of this raw material to the productive sector.
\end{abstract}

Keywords: pyrogenic carbon, waste recovery, wood industry residues

\section{Introduction}

The production of organic waste is high and growing in both rural and urban areas. Great part of the solid waste, including sawdust, are deposited inappropriately near cities or in rural areas, resulting in material potentially liable to spontaneous or criminal firel, fact worsened in the dry season. They also imply negative environmental impacts, which range from immobilization of nutrients by microorganisms and even cause serious problems such as contamination of water reserves (Silva, 2008).

There are numerous forms of waste processing aiming its stabilization. Among them stands out the pyrolysis method to obtain biochar and subsequent use in agricultural systems.

Biochar is a carbon-rich product obtained from the thermal decomposition of organic materials with atmosphere in absence or minimal presence of oxygen at temperatures ranging from 350 to $700{ }^{\circ} \mathrm{C}$, used as a soil conditioner (Lehmann, 2009). Almost any source of biomass can be carbonized (Maia \& Sohi, 2010).

According to Madari et al. (2009), the amount of carbon produced by burning depends on the source material, the temperature and time of firing. The yield of the pyrolysis process can range $12-35 \%$, depending on the kind of process used - slow or fast pyrolysis (Bridgwater, 2001). 
When added to soil, biochar can improve its physico-chemical and biological characteristics. Effects such as density reduction, porosity increase and water retention in soil, aggregate formation and improvement of the sorption complex are commonly reported. Biochar can also promote absorption of soluble organic compounds due to its polycyclic aromatic structures. Such structures are the core of biochar and explain its stability and chemical activity and when this core brings organic functions as carboxyls and hydroxyls at the border, it can increased exchangeable capacity and agronomic efficiency of fertilization (Benites et al., 2005; Novotny et al., 2009; Atkinson et al., 2010). Besides, biochar provides changes in soil microbial communities, increasing biodiversity and consenquently enhancing agricultural productivity. Some studies also report a suppression or decreasing of methane emissions and nitrous oxides (Novotny et al., 2012).

According to Casselman (2007), as the biochar does not decompose easily, its structure could hold, for thousands of years, all carbon contained in it, instead of releasing it into the atmosphere as $\mathrm{CO}_{2}$, the main greenhouse gas. This fact can contribute to increasing agricultural productivity by enhancing the ability to retain nutrients and moisture in addition to sequestering carbon and reduce the greenhouse effect.

Biochar can be described as a porous carbonaceous material, rich in pyrogenic carbon, which structure varies according to the pyrolysis process. The material is usually of high chemical stability, but when submitted to wheater action or to physical/chemical activation processes it presents a high porous density (Hammes \& Schmidt, 2009; Downie et al., 2009).

The activation process will act unclogging the surface pores from residual tar, increasing the specific surface and the number and the size of pores in the final material. This feature will also influence the development of possible surface charges originated through chemical reactions during the pyrolysis process or later, once applied in soil. This treatment improves the biochar properties as a soil conditioner and can be obtained by different methods, resulting in a higher adsorption capacity (Zhang et al., 2013).

Activated biochar has properties to be applied to soil or as a component of growing media (substrate or potting soil) to produce seedlings, since it is light and has porous, reactive structure and appropriate physical and hydraulic properties (Verheijen et al., 2010). Growing media for seedlings production must be of low density and exhibit good water retention capacity (Gonçalves et al., 2000).

According to Terra et al. (2011), a good substrate shall provide, aside low density and high capacity of water retention, high cation exchange capacity, good aeration and drainage. When added to a growing media, biochar increases its water retention ability at both low and high pressures, favoring conditions for seedlings development (Zannetti et al., 2003; Souza et al., 2006).

However, there are few studies evaluating the direct effect of biochar and their mechanisms of action on soil processes and plant growing media. Furthermore, new growing media constituents for seedling production are highly important for the nursery sector, since the substrate is a key factor for the development of seedlings and the use of materials as peat, the most common used in growing media, are not always environmental friendly.

Cavalcante et al. (2012) states that biochar has been well studied as a soil conditioner, but little information is available on biochar as a substrate component for production of fruit seedlings. However, the authors stress the importance of biochar as a substrate component especially for the production of seedlings whose propagation is economically viable, such as the yellow passion fruit.

In this context, the main objective of this study was to evaluate different growing media mixtures, including biochar (B) and activated biochar (AB), at various proportions, and its effects on the growth of passion fruit seedlings.

\section{Material and Methods}

Characterization of the study area: the trial was conducted at nursery Flora Sinop, from May to July 2013. The nursery is located in Sinop, Mato Grosso, $500 \mathrm{~km}$ far from the state capital Cuiabá, with $384 \mathrm{~m}$ above sea level and geographic location of $11^{\circ} 52^{\prime} 23^{\prime \prime}$ South, $55^{\circ} 29^{\prime} 54^{\prime \prime}$ West. The annual average temperature is $24^{\circ} \mathrm{C}$, annual rainfall of $1.900 \mathrm{~mm}$ and relative humidity ranging between 80 and 35\% during the year (Souza et al., 2012).

The sawdust to produce biochar was taken from timber industries, which process wood from native forest management systems located in Sinop/MT region. Biochar (B) was produced from fresh sawdust of tropical native species, obtained from local sawmills, in a slow pyrolysis reactor (vertical furnace), with 25 minutes of residence time in the oven, at $450^{\circ} \mathrm{C}$. 
Activated biochar (AB) was prepared in a slow pyrolysis reactor (horizontal tubular oven) at $650{ }^{\circ} \mathrm{C}$, with 60 minutes of residence time under steam injection. After activation, the proportion of phenols $(-\mathrm{OH})$ decrease and the relative amount of carboxyl $(-\mathrm{COOH})$ and lactones $(-\mathrm{OCOH})$ groups increase.

The chemical composition of the AB was $10 \%$ phenol, $40 \%$ lactose, $50 \%$ carboxyl groups and to B: $49 \%$ phenol, $21 \%$ lactose and $30 \%$ carboxyl groups showing that there are some degree of funcionalization during this process. These results were obtained by the method of Fidel (2012), and Tsechansky and Graber (2014). Carboxyl groups, being a stronger acid group than hydroxyl, can dissociate as carboxylate, creating anionic charges and increasing the cationic exchange capacity of biochar. Linhares et al. (2012) says that biochar interaction with the environment can form new compounds with carboxyl groups directly connected to the charcoal recalcitrant aromatic structures, contributing to the cation exchange capacity.

Passion fruit (Passiflora edulis Sims, BRSGA1 variety-Yellow Giant) seedlings were grown in conical tubes with a capacity of $300 \mathrm{~cm}^{3}$ of substrate. Three seeds per tube were sown and after 15 days, thinning was done leaving one seedling per container. The tubes were kept in trays containing 40 seedlings each. From each trail, only the ten central plants were evaluated, avoiding the edge effect. After 20 days, seedlings were relocated to a shaded house, with $50 \%$ of solar radiation attenuation, and after 30 days of sowing, seedlings were taken to full sun. In early production stages, the seedlings density per tray was one per cell. In full sun environment, seedlings were redistributed to the density of one plant every four cells.

The experiment consisted of four replicated in randomized blocks, each sample unit (plot) represented by 20 seedlings. Ten treatments were included: Commercial Substrate (CS) composed by pine bark and vermiculite $(4: 1, \mathrm{~m} / \mathrm{m})$; local Nursery Substrate (NS) composed by carbonized rice husk and coconut fiber $(1: 1, \mathrm{~m} / \mathrm{m})$; binaries mixtures of $\mathrm{CS}$ and $\mathrm{B}$ or $\mathrm{AB}$ at proportion of: 25; 50; 75; and 100\% (B25, B50, B75, B100, AB25, AB50, $\mathrm{AB} 75$ and $\mathrm{AB} 100$, respectively), as represented in Figure 1.

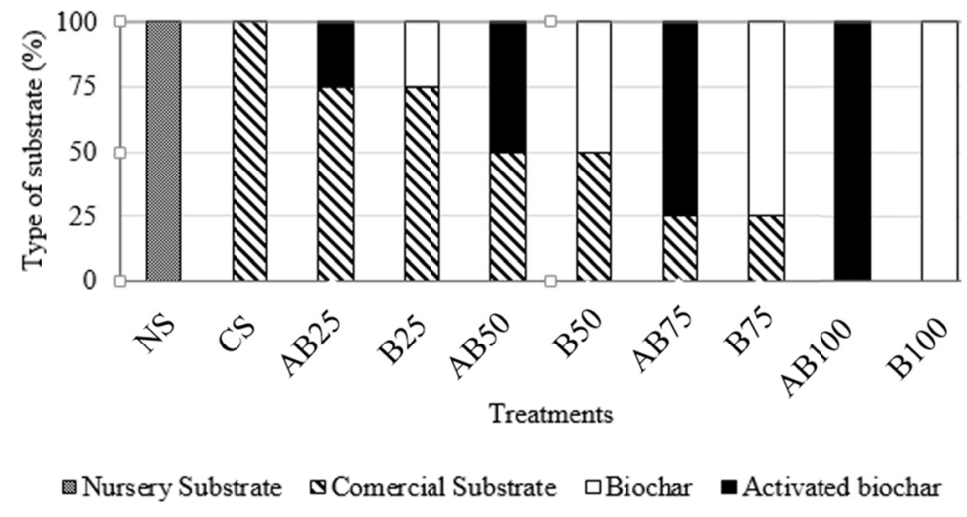

Figure 1. Types of substrate

The trial was conducted for 60 days under controlled conditions with temperatures around $30{ }^{\circ} \mathrm{C}$ and relative humidity above $80 \%$. The seedlings were watered by sprinkling twice daily.

The physical characteristics of the substrate are show in Table 1.

Table 1. Physical properties of the substrates

\begin{tabular}{llcl}
\hline Substrates & Real density & Apparently density & Porosity \\
\hline & $---1 .-16$ & 0.47 & $\%$ \\
CS & 1.16 & 0.15 & 59 \\
NS & 1.02 & 0.24 & 85 \\
BA & 1.67 & 0.31 & 85 \\
B & 1.27 & & 75 \\
\hline
\end{tabular}


The different substrates were homogeneized with an electric mixer and chemical slow release fertilizers were added equally for all treatments ( $225 \mathrm{~g}$ Basacote ${ }^{\circledR} 6 \mathrm{M} ; 225 \mathrm{~g}$ Basacote ${ }^{\circledR} 3 \mathrm{M}$ and $600 \mathrm{~g}$ FH Eucalipto Heringer ${ }^{\circledR}$ to $150 \mathrm{~L}$ of substrate). The composition of Basacote ${ }^{\circledR} 6 \mathrm{M}$ and Basacote ${ }^{\circledR} 3 \mathrm{M}$ is $16-08-12$ of NPK, micronutrient content: $\mathrm{Mg}-2 \%, \mathrm{~S}-5 \%, \mathrm{Fe}-0.4 \%, \mathrm{~B}-0.02 \%, \mathrm{Zn}-0.02 \%, \mathrm{Cu}-0.05 \%$ and $\mathrm{Mn}-0.06 \%$; and the composition of FH Eucalipto Heringer ${ }^{\circledR}$ is $4-31-4$ of NPK, micronutrient content: $\mathrm{Zn}-0.4 \%$ and $\mathrm{Co}-22 \%$ respectively.

Height was measured with a millimetric ruler, the stem diameter was measured with a precision digital caliper $(0.01 \mathrm{~mm})$. After 60 days, the seedlings were taken for determination of fresh and dry weight of shoot and root.

Fonseca et al. (2002) describes the DQI as a good indicator of seedlings quality, because it considers robustness and biomass equilibrium distribution in the plant. We calculated the Dickson Quality Index (DQI) (Dickson et al., 1960) according to the following equation:

$$
\mathrm{QID}=\frac{\mathrm{TDM}}{\frac{\text { height }}{\text { stem diameter }}+\frac{\text { SDM }}{\mathrm{RDM}}}
$$

Where, DQI: Dickson Quality Index; TDM: Total Dry Biomass (g); SDM: Shoot Dry Mass (g); RDM: Root Dry Mass $(\mathrm{g})$; height $(\mathrm{cm})$ stem diameter $(\mathrm{mm})$.

All data were submitted to the average test Scott-Knott at $5 \%$ probability by statistical program SISVAR (Ferreira, 2011).

\section{Results and Discussion}

Growing media containing 25,50 and $75 \%$ of $\mathrm{AB}$ produced the higher increases in fresh and dry total biomass, fresh biomass of root and aerial biomass and dry biomass of root and stem. The increases in total fresh biomasses in treatments containing 25,50 and $75 \%$ of $\mathrm{AB}$ when compared to the NS were $24 ; 23$ and $25 \%$ and to CS were $31 ; 30$ and $32 \%$, respectively. For total dry weight, increments were 20,14 and $15 \%$ in relation to NS and 17,11 and $13 \%$ in relation to CS (Table 2). Leaves dry weight had no significant difference.

Table 2. Fresh and dry root biomass, stem and leaves; total fresh biomass and total dry biomass of passion fruit seedlings in relation to substrates

\begin{tabular}{|c|c|c|c|c|c|c|c|}
\hline \multirow{2}{*}{ Treatments } & \multicolumn{3}{|c|}{ FB $\left(\right.$ g plant $\left.^{-1}\right)$} & \multicolumn{2}{|c|}{ DB $\left(\right.$ g plant $\left.^{-1}\right)$} & \multirow{2}{*}{$\begin{array}{l}\text { Total FB } \\
\left(\text { g plant }^{-1}\right)\end{array}$} & \multirow{2}{*}{$\begin{array}{l}\text { Total DB } \\
\left(\text { g plant }^{-1}\right)\end{array}$} \\
\hline & root & stem & leaf & root & steam & & \\
\hline NS & $52.50 \mathrm{~b}$ & $27.00 \mathrm{c}$ & $49.00 \mathrm{~b}$ & $1.03 \mathrm{a}$ & $0.66 \mathrm{c}$ & $127.50 \mathrm{~b}$ & $2.63 \mathrm{~b}$ \\
\hline $\mathrm{CS}$ & $48.00 \mathrm{~b}$ & $23.00 \mathrm{c}$ & $41.50 \mathrm{c}$ & $1.19 \mathrm{a}$ & $0.61 \mathrm{c}$ & $116.00 \mathrm{c}$ & $2.71 \mathrm{~b}$ \\
\hline $\mathrm{AB} 25$ & $70.00 \mathrm{a}$ & $37.50 \mathrm{a}$ & $60.00 \mathrm{a}$ & $1.37 \mathrm{a}$ & $0.80 \mathrm{~b}$ & $168.00 \mathrm{a}$ & $3.27 \mathrm{a}$ \\
\hline B25 & $58.50 \mathrm{a}$ & $27.00 \mathrm{c}$ & $46.00 \mathrm{~b}$ & $0.91 \mathrm{~b}$ & $0.73 \mathrm{c}$ & $133.50 \mathrm{~b}$ & $2.62 \mathrm{~b}$ \\
\hline AB50 & $66.00 \mathrm{a}$ & $38.50 \mathrm{a}$ & $58.50 \mathrm{a}$ & $1.19 \mathrm{a}$ & $0.93 \mathrm{a}$ & $165.00 \mathrm{a}$ & $3.05 \mathrm{a}$ \\
\hline B50 & $43.50 \mathrm{~b}$ & $30.50 \mathrm{~b}$ & $38.50 \mathrm{c}$ & $0.69 \mathrm{~b}$ & $0.60 \mathrm{c}$ & $112.50 \mathrm{c}$ & $2.13 \mathrm{c}$ \\
\hline AB75 & $71.00 \mathrm{a}$ & $39.00 \mathrm{a}$ & $62.50 \mathrm{a}$ & $0.92 \mathrm{~b}$ & $0.94 \mathrm{a}$ & $169.50 \mathrm{a}$ & $3.11 \mathrm{a}$ \\
\hline B75 & $42.50 \mathrm{~b}$ & $24.00 \mathrm{c}$ & $37.50 \mathrm{c}$ & $0.66 \mathrm{~b}$ & $0.66 \mathrm{c}$ & $105.00 \mathrm{c}$ & $2.13 \mathrm{c}$ \\
\hline $\mathrm{AB}$ & $45.00 \mathrm{~b}$ & $32.00 \mathrm{~b}$ & $50.50 \mathrm{~b}$ & $0.70 \mathrm{~b}$ & $0.75 \mathrm{c}$ & $127.00 \mathrm{~b}$ & $2.50 \mathrm{c}$ \\
\hline B & $35.50 \mathrm{~b}$ & $21.00 \mathrm{c}$ & $37.00 \mathrm{c}$ & $0.60 \mathrm{~b}$ & $0.55 \mathrm{c}$ & $94.50 \mathrm{c}$ & $1.95 \mathrm{c}$ \\
\hline $\mathrm{CV} \%$ & 21.69 & 14.55 & 9.56 & 24.11 & 12.39 & 11.61 & 14.20 \\
\hline
\end{tabular}

Note. FB - fresh biomass, DB - dry biomass, NS - nursery substrate, $\mathrm{CS}$ - comercial substrate, $\mathrm{AB}$ - activated biochar, B - biochar.

* Means followed by the same letter do not differ by the Scott-Knott test $(\mathrm{p}<0.05)$.

Plant height and stem diameter showed significantly increases for treatments AB25, AB50 and AB75 (Figures $2 \mathrm{~B}$ and $2 \mathrm{C}$ ). For number of leaves in passion fruit seedlings, all doses with activated biochar were higher than other treatments (Figure 2A). 

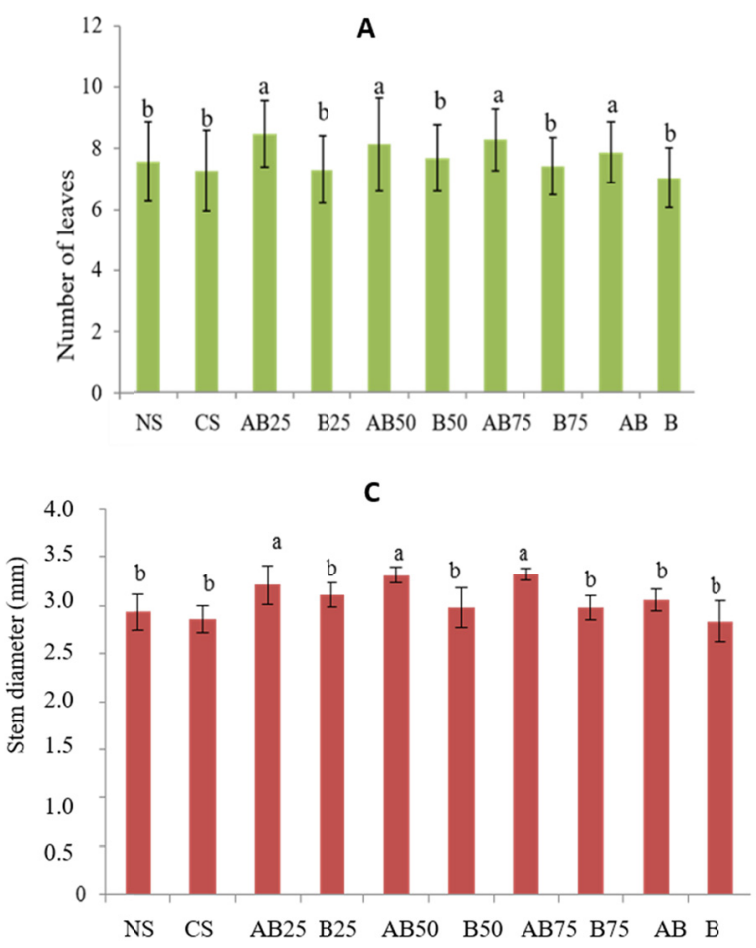
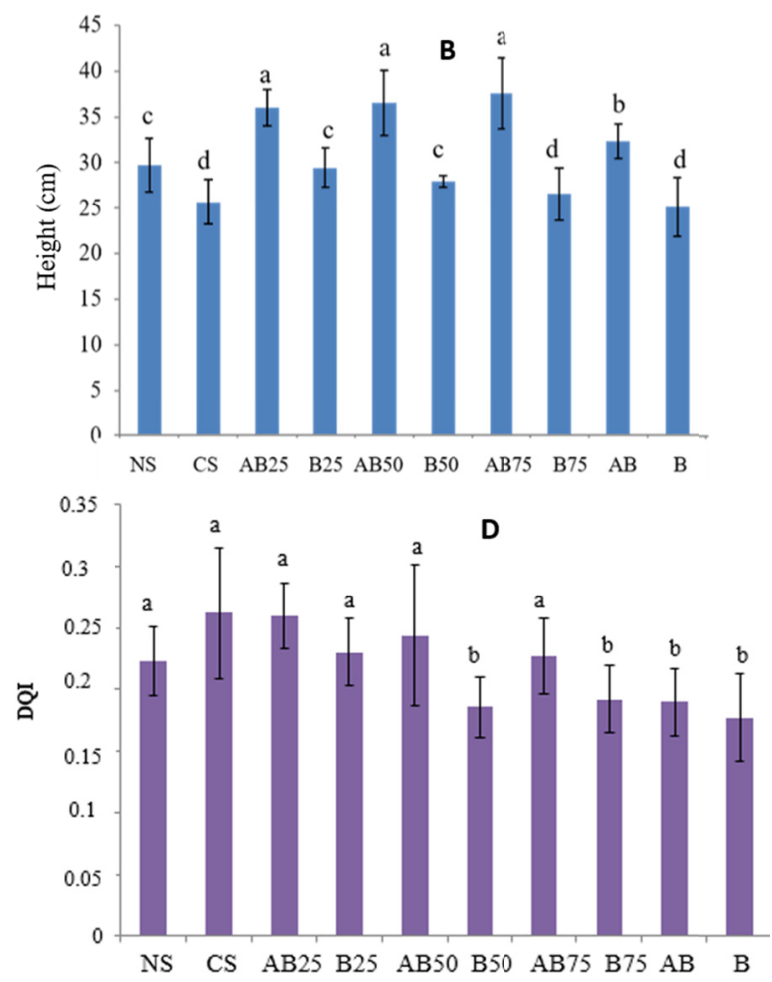

Figure 2. A - number of leaves; B - height; $\mathrm{C}$ - stem diameter; D - DQI after 60 days

Note. Means followed by the same letter do not differ by the Scott-Knott test $(\mathrm{p}<0.05)$.

The Dickson Quality Index (DQI) is shown in Figure 2D. The DQI vary from 0.18 to 0.26 . Treatments NS, CS, AB25, B25, AB50, AB75 showed higher values but did not differ statistically among them, by the Scott-Knott test at $5 \%$ probability. They showed values as recommended by Hunt (1990), which established default values greater than or equal to 0.20 for quality of seedlings. This author says that DQI smaller than 0.20 indicate seedlings with poor final quality to go to the field and DQI above this value present better quality.

Fonseca et al. (2002) state that the Dickson quality index is a good indicator of quality because it takes into account the balance of the distribution of biomass, being an important parameter to be used in assessing the quality of seedlings.

The most labile substrate has a greater mineralization rate, with higher cation exchange capacity provided by the peripheral charges in addition to the physico-hydric effects, which was provided by the activation process. The activation process can promote both the release of volatiles and formation of crystalline $\mathrm{C}$ formation, unclogging of biochar pores and improvement of loads of organic radicals in the carbon surface, increasing the surface area and porosity, which facilitates the action of the mineralizing microorganisms (Downie et al., 2009; Bruun et al., 2012; Morales, 2010). These effects influence the greater accumulation of fresh and dry matter with activated biochar added to the commercial substrate.

The activated biochar porosity was higher when compared to the commercial substrate and biochar. Thus, activated biochar contributed to increase porosity, aeration and water holding capacity when mixed with soil or substrate, an essencial factor for the quality of the substrate (Zanetti et al., 2003).

Another explanation is the chemical composition of the activated biochar, which showed $50 \%$ of carboxylic groups $10 \%$ of phenolic groups. Despite the biochar be considered an inert material, it can bring in its molecular structure sites with potential capacity to perform ion exchange, which can contribute to increased cation exchange capacity (CEC) values and thus provide greater availability of nutrients (Novotny et al., 2009).

Cavalcante et al. (2012), state that the root system is in direct contact with the substrate and thus the positive or negative effects of the growth medium can influence the performance of the cultures. Therefore, the activated biochar when added to commercial substrate showed beneficial effects in the production of passion fruit seedlings. 
These results are consistent with those presented by Mendonça et al. (2003), who used charcoal combined with cattle manure + soil and sand in the ratio 1: 2: 1: $1 \mathrm{v} / \mathrm{v}$ in the production of papaya seedlings, and obtained around $34 \%$ in average higher total fresh and dry weight than the control.

Mendonça et al. (2003), and Souza et al. (2006) studies, showed height gain when added charcoal in the composition of the substrate.

The results of this study also corroborate with Gaskin et al. (2010), Junior Marimon et al. (2012) and Petter et al. (2012) confirming the benefic effects in the combination of biochar and chemical fertilizers, superior then fertilizers alone, in plant growth and crop productivity.

The activation of biochar positively influenced the formation of yellow passion fruit seedlings. In this study, lower doses of biochar, both activated and non-activated, positively influenced the quality of seedlings. Therefore, further studies with different forms of biochar activation and/or combinations are particularly recommended in the production of fruit seedlings.

When considering the adoption of the technique by nurseries and fruit production sector, the results achieved here showed the most recommended dose would be the addition of $25 \%$ activated biochar.

\section{Conclusions}

The studied variables were significantly influenced by the application of activated biochar when added to commercial substrate Mec plant ${ }^{\circledR}$. Biochar activated at concentrations 25, 50 and $75 \%$ combined with Mec plant ${ }^{\circledR}$ showed increases in parameters total fresh and dry biomass, height, stem diameter and number of leaves.

The dose of $25 \%$ activated biochar showed the best results when added to commercial substrate.

Sawdust processed into activated biochar is an alternative to improve passion productivity and to recycle this raw material into the production sector.

The study of economic feasibility should be carried out throughout the production system for recommending the use of biochar in passion fruit culture.

\section{References}

Benites, V. M., Mendonça, E. S., Schaefer, C. E. G. R., Novontny, E. H., Reis, E. L., \& Ker, J. C. (2005). Properties of black soil humic acids from high altitude rocky complexes in Brazil. Geoderma, 127(1-2), 104-113. https://doi.org/10.1016/j.geoderma.2004.11.020

Bridgwater, A. V. (1991). Review of Thermochemical Biomass Conversion. Report B 202, Energy Technology Support Unit (UK).

Bruun, E. W., Ambus, P., Egsgaard, H., \& Hauggaard-Nielsen, H. (2012). Effects of slow and fast pyrolysis biochar on soil $\mathrm{C}$ and $\mathrm{N}$ turnover dynamics. Soil Biology and Biochemistry, 46(1), 73-79. https://doi.org/10.1016/j.soilbio.2011.11.019

Atkinson, C. J., Fitzgerald, J. D., \& Hipps, N. A. (2010). Potential mechanisms for achieving agricultural benefits from biochar application to temperate soils: A review. Plant and Soil, 337(1), 1-18. https://doi.org/10.1007/s11104-010-0464-5

Casselman, A. (2007). Special Report: Inspired by Ancient Amazonians, a Plan to Convert Trash into Environmental Treasure. Scientific American, 67, 2.

Cavalcante, L., Herbert, Í., Petter, F. A., Albano, F. G., Silva, R. R. S., \& Silva Júnior, G. B. (2012). Biochar no substrato para produção de mudas de maracujazeiro amarelo. Rev. Fac. Agron., 111(1), 41-47. Retrieved from http://hdl.handle.net/10915/41886

Dickson, A., Leaf, A. L., \& Hosner, J. F. (1960). Quality appraisal of white spruce and white pine seedling stock in nurseries. Forest Chronicle, 36, 10-13. https://doi.org/10.5558/tfc36010-1

Downie, A., \& Crosky, A. (2009). Munroe, P. Physical Properties of Biochar. In J. Lehmann, \& S. Joseph (Eds.), Biochar for environmental management: Science and technology (pp. 13-29). Londres: Earthscan.

Ferreira, D. F. (2011). Sisvar: A computer statistical analysis system. Ciência e Agrotecnologia, Lavras, 35(6), 1039-1042.

Fonseca, É. P., Valeri, S. V., Miglioranza, E., Fonseca, N. A. N., \& Couto, L. (2002). Padrão de qualidade de mudas de Trema micrantha (L.) Blume, produzidas sob diferentes períodos de sombreamento. Revista Árvore, Viçosa, 26(4), 515-523. https://doi.org/10.1590/S0100-67622002000400015 
Gaskin, J. W., Speir, R. A., Harris, K., Das, K. C., Lee, R. D., Morris, L. A., \& Fisher, D. S. (2010). Effect of peanut hull and pine chip biochar on soil nutrients, corn nutrient status, and yield. Agronomy Journal, 102(2), 623-633. https://doi.org/10.2134/agronj2009.0083

Gonçalves, J. L. M., Santarelli, E. G., Neto, S. P. M., \& Manara, M. P. (2000). Produção de mudas de espécies nativas:Substrato, nutrição, sombreamento e fertilização. In J. L. M. Gonçalves, \& V. Benedetti (Eds.), Nutrição e fertilização florestal (Cap. 11, pp. 80-102). Piracicaba: IPEF.

Hammes, K., \& Schimidt, M. W. I. (2009). Changes of biochar in soil. In J. Lehmann, \& S. Joseph (Eds.), Biochar for environmental management: Science and technology (pp. 169-178). Londres: Earthscan.

Hunt, G. A. (1990). Effect of styroblock design and cooper treatment on morphology of conifer seedlings. Proceedings of Target seedling symposium, meeting of the western forest nursery associations, general technichal report RM-200, 1990, Roseburg (pp. 218-222). Fort Collins: United States Departament of Agriculture, Forest Service.

Lehmann, J. (2009). Biochar for Environmental Management. Earthscan, Oxford, UK.

Lehmann, J., Rillig, M. C., Thies, J., Masiello, C. A., Hockaday, W. C., \& Crowley, D. (2011). Biochar effects on soil biota - A review. Soil and Biochemistry, 43, 1812-1836. https://doi.org/10.1016/j.soilbio.2011.04.022

Linhares, C. R., Lemke, J., Auccaise, R., Duó, D. A., Ziolli, R. L., Kwapinski, W., \& Novotny, E. H. (2012). Reproducing the organic matter model of anthropogenic dark earth of Amazonia and testing the ecotoxicity of functionalized charcoal compounds. Pesquisa Agropecuária Brasileira, 47, 693-698, https://doi.org/10.1590/S0100-204X2012000500009

Madari, B. E., Cunha, T. J. F., Novotny, E. H., Milori, D. M. B. P., Martin Neto, L., Benites, V. M., ... Santos, G. A. (2009). Matéria orgânica dos solos antrópicos da Amazônia (terra preta de índio). Suas características e papel na sustentabilidade da fertilidade do solo. Em: As terras pretas de índio da Amazônia: sua caracterização e uso deste conhecimento na criação de novas áreas (pp. 172-188). Embrapa Amazônia Ocidental, Manaus.

Maia, C. M. B. F., \& Sohi, S. P. (2010). The effect of biochar on soil-carbon stabilization in a highly SOM-depleted soil. Proceedings of 3rd IBI Meeting, Rio de Janeiro.

Marimon-Junior, B. H., Petter, F. A., Andrade, F., Madari, B. E., Marimon, B. S., Schossler, T. R., ... Belém, R. S. (2012). Produção de mudas de jiló em substrato condicionado com Biochar. Comunicata Scientiae, 3(2), 108-114.

Mendonça, V., Neto, S. E. de A., Ramos, J. D., Pio, R., \& Gontijo, T. C. A. (2003). Diferentes substratos e recipientes na formação de mudas de mamoeiro 'Sunrise Solo'. Revista Brasileira de Fruticultura, 25(1), 127-130. https://doi.org/10.1590/S0100-29452003000100036

Morales, M. M. (2010). Efeito do biocarvão sobre o comportamento da matéria orgânica e do fósforo em solo degradado (p. 75). Tese Doutorado. Botucatu, SP, UNESP.

Novotny, E. H., Hayes, M. H. B., Madari, B. E., Bonagamba, T. J., Azevedo, E. R. D., Souza, A. A. D., ... Mangrich, A. S. (2009). Lessons from the Terra Preta de Índios of the Amazon Region for the utilization of Charcoal for Soil Amendment. Journal of the Brazilian Chemical Society, Campinas, 20(6), 1-8.

Novotny, E. H., Madari, B. E., Maia, C. M. B. F., \& Mangrich, A. S. O. (2012). Potencial do Biocarvão (Carbono Pirogênico) no Sequestro de Carbono; na Ciclagem de Nutrientes; no Crescimento das Plantas e no Estímulo de Processos Microbiológicos. In Fertibio 2012. Anais ... Maceió, AL.

Petter, F. A., Madari, B. E., Silva, M. A. S. da, Carneiro, M. A. C., Carvalho, M. T. de M., Júnior, B. H. M., Pacheco, L. P. (2012). Soil fertility and agronomic response of rice to biochar application in the Brazilian savannah. Pesquisa Agropecuária Brasileira, 47(5), 699-706. https://doi.org/10.1590/S0100-204X201 2000500010

Silva, C. A. (2008). Uso de resíduos orgânicos na agricultura. In G. A. Santos, et al. (Eds.), Fundamentos da matéria orgânica: Ecossistemas tropicais e subtropicais (Cap. 32, pp. 597-624). Porto Alegre: Metrópole.

Souza, G. K. A. D., Teixeira, W. G., Reis, R. A., Chaves, F. C. M., \& Xavier, J. J. B. N. (2006). Growth of Crajiru (Arrabidaea chica Verlot.) in different growing media. Revista Brasileira de Plantas Medicinais, 8, 61-65.

Souza, A. P., Casavecchia, B. H., \& Stangerlin, D. M. (2012). Avaliação dos riscos de ocorrência de incêndios florestais nas regiões Norte e Noroeste da Amazônia Matogrossense. Scientia Plena, 8(5), 5. 
Terra, S. B., Ferreira, A. A. F., Peil, R. M. N., Stumpf, E. R. T., Beckmann-Cavalcante, M. Z., \& Cavalcante, Í. H. L. (2011). Alternative substrates for growth and production of potted Chrysanthemum (cv. Funny). Acta Scientiarum. Agronomy, 33, 465-471.

Verheijen, F., Jeffery, S., Bastos, A. C., Van Der Velde, M., \& Diafas, I. (2010). Biochar Application to Soils: A Critical Scientific Review of Effects on Soil Properties, Processes and Functions (p. 166). Luxembourg: Office for Official Publications of the European Communities, European Communities.

Zanetti, M., Cazetta, J. O., Mattos Júnior, D., \& Carvalho, S. A. (2003). Uso de subprodutos de carvão vegetal na formação do porta-enxerto limoeiro 'Cravo' em ambiente protegido. Revista Brasileira de Fruticultura, 25(3), 508-512. https://doi.org/10.1590/S0100-29452003000300037

Zhang, M., Gao, B., Varnoosfaderani, S., Hebard, A., Yao, Y., \& Inyang, M. (2013). Preparation and characterization of a novel magnetic biochar for arsenic removal. Bioresource Technology, 130, 457-462. https://doi.org/10.1016/j.biortech.2012.11.132

\section{Copyrights}

Copyright for this article is retained by the author(s), with first publication rights granted to the journal.

This is an open-access article distributed under the terms and conditions of the Creative Commons Attribution license (http://creativecommons.org/licenses/by/4.0/). 